\title{
THE JOURNAL OF MENTAL SCIENCE.
}

\begin{tabular}{lll}
\hline \hline No. 50. & JULY, 1864. & Vor. X. \\
\hline \hline
\end{tabular}

PART I.-ORIGINAL ARTICLES.

\section{The Classification of the Sciences.}

So extensive is the field of human knowledge, so many and wide apart are the spots at which ground has been broken, and so evident is the necessity for men to be special in their studies if they would be thoroughly masters of their subjects, that there is no little danger lest workers in one department may be unappreciated by, if not actually unknown to, those who are employed in another part. Any one who will give his attention to the matter may observe examples of lines of investigation, which have really close relations, and the results of which might be of mutual aid, running side by side, like parallel lines, without meeting. Accordingly, M. Comte was of opinion that there was needed a new order of scientific men, whose function it should be to bring together and co-ordinate the results of the different workers; and it is plain that such an organisation must be effected somehow. But great mischief would of a certainty result from men specially undertaking this work: unless they are thoroughly and practically grounded in some science, unless they have plodded in patient and tedious investigation, they are almost sure to go astray into vain and seductive speculations, which are never definite enough to be useful, are often enticing enough to be mischievous. If a valuable idea is perchance hit upon, it is potential rather than real, as a statue is potential in a block of marble, though it has yet to be hewn out; it is so shrouded in theoretical haze, and so much wanting in exactness, that it is of no value until the patient work of the practical men has defined it, put it in its proper place, and so to speak guaranteed its worth. Even Goethe, exceptionally powerful as his mind was, and much as he worked, owed his scientific troubles and his scientific errors to a

vol. $x$. 
want of practical knowledge. Those who have not had a scientific training must lack the scientific innagination.

Then again, such men would be apt to be continually discovering what was very well known; the idea being new to them, they think it must be absolutely new, and all the while it is familiar as a household word in the science. No better example of this disposition could be given than is afforded by Mr. Lewes, who has on several occasions blown the trumpet of discovery over a very elementary scientific notion, which was new to no one but himself. Not only has it not been a new idea in such case, but it has actually been more correctly interpreted and valued long ago than it now is by its new patron who has just awakened to its existence; for another fault of men like Mr. Lewes is that, being deficient in that exact knowledge which a practical scientific education can alone give, they overestimate the idea, do not appreciate modifying considerations, and make false by exaggeration what had some truth in it at first. Nothing is easier than to make discoveries in a science with which one has but a superficial acquaintance; nothing is more difficult than to make discoveries in a science when the knowledge of it is profound and practical. Divorce a scientific thinker from actual observation, and he is only a little less bad than the scholastic writers who, altogether divorced from nature, spun endless webs out of their own minds.

For the foregoing reasons it is questionable whether a sufficiently competent special order of men will ever be available for the coordination of the results of the different sciences-this highest task of the scientific intellect. It will be necessary to rely upon the coming of a special man, one who, excellently endowed by nature and thoroughly well trained, shall rise up by a natural necessity from his special department, and do the work of organization. The work in truth demands such special and uncommon gifts, and such a complete systematic scientific training, that a class of men equal to it can never be depended upon : one must rest in hope that whenever the material is sufficiently prepared the required man will appear. But of all men deliver us from those who make a profession of being universal-who will write you, with equal assurance, a sermon, a novel, a drama, or a scientific essay.

$\Delta t$ the present time it behores science to be especially on its guard against those who are metaphysically minded. " $O$ physics," said Newton, "beware of metaphysics!" The danger is not now from an open adversary, but from a concealed enemy, which, having made its way into the camp under a disguise, watches its opportunity to be traitor. Metaphysics is a very subtle serpent, which has been severely scotched, but not killed; and knowing right well that an open appearance would be instant death, it creeps, with the cunning of its kind, into hidden crevices, and works its mischievous work in 
secret. It would be no injustice to say that all that is valuable in recent metaphysics, all that really constitute a progress, is not merely an unacknowledged but a disguised appropriation from the physiologist: it steals the physiologiat's facts, drags them into its den, gives them new names, and then dares him to recognise or reclaim them. Reclaim them ! Heaven forbid! They will bring their orn retribution by turning the metaphysician out of house ultimately ; but meanwhile he would do well to keep to his own ground: it is not to be tolerated that he invade the territory of true science, and establish his noxious business there. Metaphysicy in its relation to science is not unlike a race of feeble natives in contact with the strong race of a vigorous and thriving colony, before which they must perish : feeble, like the degenerate native, it takes refuge in cunning, retreats to the bush, and for a time supports itself by stealing; but rendered bold by long impunity, or driven on by a fatal necessity, it makes a too impudent assault, and rushes upon its unavoidable end.

It is natural to expect that whilot this process of extinction is going on, as it seems to be going on at present, there should be marks of its different stages in current literature; for writers are the products of their centuries, and reflect the tendencies of their age. Sir W. Hamilton was himself scarcely a pure metaphysician, his chief merit lying in that in which he was not metaphysical; and since his death it has been hardly possible to meet with a meta. physician of any sort. Perhaps Mr. Mansel represents as perfect a specimen as can be found, and he is, so to speak, no more than a 'Religious Tract Society' edition of Sir W. Hamilton. While Mr. Mansel thus marks the extreme of backwardness, the present clinging to the past and unwilling to let it go, Mr. Bain, on the other hand, may be taken as the representative of progreas; his elaborate and careful works on psychology must have rendered it a very hard matter for any one, however ignorant of physiology, agaim to write metaphysically about the mind. Intermediate between these two is Mr. Herbert Spencer, who has acquired a high position as a philosuphical writer, but who yet bears about with him the badge of a metaphysical bondage. It was to him, however, that we wished to come, and have been labouring through the foregoing observations to come.

But what, it may be asked, have such discursive reflections to do with Mr. Spencer? Just this: that there appears to be some danger lest the value of so good and thoughtsul a writer should be lessened, and his power be uselessly dissipated, by reason of a manifest disposition which he has to stumble into those bogs that have been indicated. Probably there is not in all literature another instance of so much being made of one idea as Mr. Spencer has made of Von Baer's idea of progress from the general to the special 
in development; he has taken it up and hunted it with such a remarkable perseverance and ingenuity through every department of life, particular and general, that his results are sometimes fanciful. Then again, he has lately wandered into biological speculations which, though ingenious enough, have no sufficient basis in facts, and seem, indeed, to betoken an inadequate knowledge of what really has been done in the way of positive investigation. Lastly, he has offended by the exhibition of a metaphysical tendency which damages the savour of his science, and will greatly impede his usefulness, if it does not completely wreck him. 'He has this great merit, however, that he is not superficial; and, accordingly, he is instructive where he does not produce assent, not unfrequently stimulating the reader's mind to the severe examination of his reasons for dissent, and to the consequent formation of exact ideas. No apology, then, is needed for bringing specially to the notice of the readers of the 'Journal of Mental Science' a writer whom every one may read with the greatest profit, and, we may add, without reading whom one can scarcely be properly furnished for the scientific study of mind.*

Mr. Spencer's position as a thinker is fairly represented in his work on the 'Principles of Psychology', published some years ago. In the first part of the book, a metaphysical notion that " a belief which is proved by the inconceivableness of its negation to invariably exist, is true," completely runs away with him into regions of infinite vanity; but of this test we need say no more here than that, in the stern grasp of Mr. J. S. Mill, it collapses, as a child's cleverly blown soap-bubble might be supposed to collapse in the hand of a giant. For the bubble was a cleverly blown one; and, in truth, it is the marvellous expenditure of ingenuity on such a vanity which is calculated to implant a distrust of Mr. Spencer as a thinker. The second part of the 'Principles' contains a valuable contribution to philosophical literature; and it is only a matter of surprise that any one who wrote that should have written the first part. Throughout all his other writings, however, a similar antagonism is traceable; and in the appendix to a recent essay it has broken out into an exposition of his differences from and agreements with M. Comte; the result of which must be, we fear, to produce a couviction that Mr. Spencer has an insufficient knowledge of Comte's writings.

In an essay on the 'Genesis of Science,' published in 1854, Mr. Spencer endeavoured to show that the sciences cannot rightly be arranged in any serial order, logical or historical. This was in opposition to M. Comte, who arranged them in succession thus :-

- The opportunity is favorable, as Mr. Spencer proposes to issue in periodical parts a series of works comprising - 1. First Principles. 2. The Principles of Biology. 8. The Principles of Paychology. 4. The Principles of Sociology. 5. The Principles of Morality. 
Mathematics, astronomy, physics, chemistry, physiology, and sociology; such arrangement being, said $\mathbf{M}$. Comte, "the only one which logically conformed to the natural and invariable hierarchy of phenomena." In an essay on the "Classification of the Sciences,* just published, Mr. Spencer points out how their relations may be, as he thinks, rightly expressed.

The broadest natural division among the Sciences is between those which " deal with the abstract relations under which phenomena are presented to us, and those which deal with the phenomena themselves." What are the sciences which deal with abstract relations? Those which deal exclusively with space and time, namely, mathematics and logics. "Space is the abstract of all relations of coexistence. 'Time is the abstract of all relations of sequence." Logic and mathematics, then, as dealing entirely with relations of co-existence and sequence, form a class of sciences widely unlike the rest.

The sciences which deal with existences themselves admit of a less profound sub-division. They fall into two classes according as we study (1) the component modes of force of each phenomenon, or (2) the entire phenomenon as a product of the several simultaneously acting forces or co-operative factors. "The truths reached through the first kind of inquiry, though concrete inasmuch as they have actual existences for their subject-matters, are abstract inasmuch as they refer to the modes of existence apart from one another; while the truths reached by the second kind of inquiry are properly concrete, inasmuch as they formulate the facts in their combined order, as they occur in nature."

Accordingly the sciences will stand thus :-

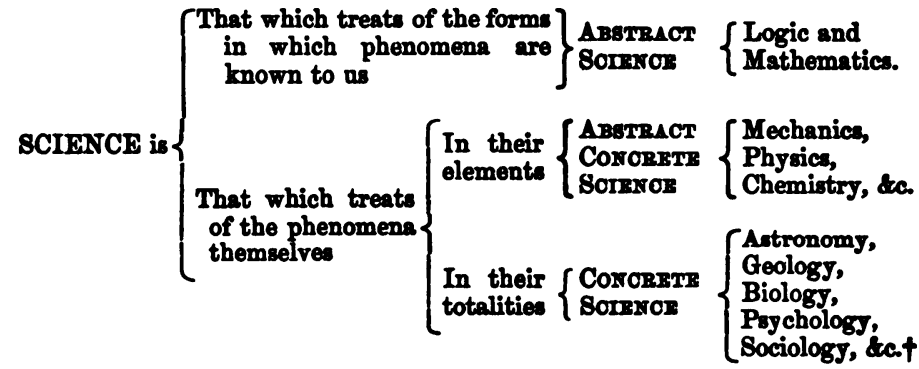

- The Classification of the Sciences: to which are added Reasons for Dirsenting from the Philosophy of M. Comte;' by Herbert Spencer. Williams and Norgate, 1864.

+ This table only represents the main division, although it must sufflce for our purposes here: in three other tables, Mr. Spencer follows out the different sub. divisions of each division, but the criticism of them in detail would be an nnprofitable and interminable busineas. 
It is obviously a first necessity, before proceeding further, to have a clear idea of what is meant by the term abstract. M. Comte divides science into abstract and concrete, but instead of considering some sciences as altogether abstract, and others as wholly concrete, he looks upon each science as having an abstract part and a concrete part, thus confusing, as Mr. Spencer thinks, the words abstract and general, which should, he says, have different meanings. Abstract means detachmont from the particular; it is concerned with the essential nature apart from the phenomena ; it is "rarely, if ever, realised in perception;" it is dravon from actual experiences, but never presented to us in any of them; it "formulates a truth which certain phenomena all involve, though it is actually seen in none of them." Such is Mr. Spencer's notion of the meaning of abstract, and it is plain from his words that he is not quite sure whether an abstract truth is sometimes realised in the perception or not. At one time he says it is "rarely, if ever," so realised; at another time he says it is never presented in our actual experiences. Making a note of that by the way, we pass on to his definition of a general truth. General truth means manifestation in the particular; it is concerned with the frequency of recurrence of the phenomena; "it may be realised in all the cases of which it is asserted ;" "it sums up a number of our actual experiences;" it "colligates a number of particular truths." Let us make an observation here, which may, perhaps, seem hypercritical, but which is of importance when the question is about the definite meaning of words. When Mr. Spencer says that a general truth "may be realised in all the cases of which it is asserted," he leaves us to suppose that sometimes it may not; so when he was speaking of abstract truth, he admitted a possibility that it might sometimes, though rarely, be realised in the perception. Well, then, if an abstract truth may be so realised, and if a general truth sometimes may not, what, dealing only with his own words, becomes of the distinction which Mr. Spencer wishes to be drawn? Is it not tolerably evident that he is himself somewhat uncertain about his fundamental distinction? And yet it is the foundation fact of his classification, that on which he rests his assertion that the abstract sciences form a class "widely unlike" the rest, that from which he assaults M. Comte, and disputes the opiniou that the three classes of sciences are distinguishable by differences only in their degrees of generality.

When Mr. Spencer speaks of an abstract truth signifying the "essential nature of some phenomenon, apart from the phenomena which disguise it," he has plainly enough in his mind a subjective generality. This essential nature, or, to adopt Coleridge's words, "this inmost principle of the possibility of the thing" is simply equivalent to the idea of the thing, if the word idea be used in its Platonic sense. This idea, form, or essence, is in trath the highest 
general conception which we can form of the thing; and the term abstract applied to such an idea is really synonymons with general. But Mr. Spencer, who accuses Comte of confounding abstract and general, should certainly have known better than to say that the abstract, in its true sense, signifies the essential nature of the pheno. menon. In its true sense, it does nothing of the kind: if rightly used according to its well-defined scholastic meaning, and as it is always used by Mr. J. S. Mill, an abstract name is a name which denotes the attribute of a thing. Man is a general name of many things ; humanity is the name of an attribute of them. White is a name of a thing or things; whiteness is the abstract name of an attribute or quality. Far, then, from putting the word to its right use, Mr. Spencer has been guilty of a wanton misappropriation of it to truths for which the name general was available and proper-a misuse which, since the time of Locke, has unfortunately been common.

Supposing, however, that the word abstract had the meaning which Mr. Spencer wrongly attributes to it, his distinction between it and general is still worth nothing at all. You do not always have what every one will admit to be a general trath palpably realised in the particular: the scientific conception of a salt in chemistry, for example, how will you find that realised in the perception? Goethe's fundamental idea of a plant, or the comparative anatomist's idea of a type-where will you find these exactly realised in the particular? In botanical science, a class contains some properties which are common to all the objects included, but it contains also others which are not possessed by all the objects. Part of the character of the Rosacee, for example, is that they have alternate stipulate leaves, and that the albumen is obliterated; but in one of the genera of the family the stipulæ are absent; and the albumen is present in another. On the other hand, you have the abstract, as Mr. Spencer attempts to define it,-in 80 far as it is a reality and not an inanity or imbecility of the mind,-realised in the particular, if you will take the same trouble to look for it, and to follow the processes which have been gone through in the formation of it, which you have to do in the case of the general conception. Whenever the generalisation is concerning the more fundamental relations of the thing, a certain mental exertion, and commonly enough a special mental culture, will be neceseary to realise its signification, to perceive its connotation. Every general idea or concoption is an abstraction, or is abstract, from the individual thing: what Mr. Spencer has actually done is to convert the word denoting the process by which a general conception is formed-namely, the abstraction -into an entity specific and transcendant, thereupon making the entity stand for certain arbitrarily selected generalisations. Consenting to misuse the word abstract as Mr. Bpencer misuses it, 
one must still logically say that the abstract only involves more activity on the part of the subject than the general; that it is, as it were, a sublimation of the less general : the abstract is certainly not dravon from the particular in the sense in which beer may be supposed to be drawn from a barrel, or a dog to be dragged away from a rabbit which it is worrying; but it is drawn from it as the flower which crowns development might be said to be drawn from the plant. General conceptions differ according to the degree in which they have been mentally fashioned and elaborated; and it is impossible for any one who does not come with a perfectly arbitrary foregone determination, to decide whether a truth shall be called general or abstract, that is, when the latter word is not used in its ancient and true meaning, but is misapplied as Mr. Spencer misapplies it.

The word general is, however, sometimes used in a different sense, to designate what may be called an objective generality. It is said, for example, that connective tissue exists generally throughout the body, or is more general than any particular organ into which it enters as an essential constituent. But that is to speak ambiguously, or rather to make great confusion by ranging under the same name ideas which have nothing in common: when you speak of the organ, you are dealing with the whole of the object, tacitly making a comparison with other like objects, and, by embracing in a general conception the properties which they have in common, abstracting the essential idea of the organ; but when you speak of the general existence of connective tissue, you are doing nothing of the sort; you are not defining its essential nature by comparison and abstraction, but merely stating a fact as to its existence. Instead of embracing in a conception its common properties, you are bringing the idea of the tissue into comparison or contrast with the idea of a body or organism in which it exists as a constituent. The element or tissue is more general than the organ, in the same sense as letters are more general than a particular word which they form, because they enter into many more words. This objective generality is plainly a different sort of generality from that which is signified by a general idea. But, apart from that generality, the physiologist has also a general conception of the essential nature, so to speak, of connective tissue as a constituent of the body, just as he has a general conception of the nature of a gland apart from any particular gland. In its simplest form, a gland is a mere pushing inwards of the mucous membrane; but the carity gets more complicated, secondary recesses are formed in it, the neck is narrowed, lengthened, and becomes a duct; and so the complication goes on step by step, until you get the most complex gland. Suggest to a physiologist the word gland, and at once this general idea of a typical gland, which is exactly realised in no gland, arises in his mind; it is the essential idea of a gland 
obtained by generalisation from a multitude of observations. The mathematician's so-called abstract idea of a circle or a triangle is no more than that; and all the superior certainty of geometry as a science is simply due to its ideal data being taken for realities, whilst the corresponding data of any physical science are recognised as hypotheses. In like manner, if the words connective tissue be suggested to a physiologist, he has at once a general conception of a particularly constituted tissue acting as the general framework of the elements of the organism - a fundamental idea of it widely different from that which any one who is not a physiologist can have, though he may know that connective tissue exists generally throughout the body. In such case the generality is subjective, not objective; abstract, not concrete, because it is dravon from the particular observation by comparison and abstraction.* Mr. Spencer seems to have entirely lost sight of the higher nature of a general truth when he made his distinction between the abstract and the general-a distinction which, as it is put by himself, seems to be obscure, uncertain, and ill-grounded, and must tend to render confusion worse confounded. What he has done is, first, entirely to misappropriate the word abstract; secondly, to draw an ill-defined and unfounded distinction between abstract (as thus wrongly used) and general; and thirdly, to fall into great confusion about subjective and objective generality. But if this criticism be true, Mr. Spencer's proposed classification at once falls to pieces. To us there seems no question that it does; but it will be well to set forth his notions in greater detail.

Abstract science deals with "relations apart from related things;" it "treats of the ideal or unoccupied forms of relations " it is "cut off in imagination" from the actual, is " vholly ideal," may be defined as the laws of the forms. Let us take logic, as forming one division of the abstract science, for illustration and test of the value of such definition. Logic has been called the science of sciences, because it sits in judgment, as it were, upon evidence; and to its rules right inference and reasoning must always conform. As abstract science is wholly ideal and concerned with the laws of form, logic must be the 'Science of the formal Laws of Thought.' That was, in fact, what the school which Sir W. Hamilton represented conceived it to be. It is not our business to dispute whether it is a right definition of logic or not; but it is plain that Mr. Spencer's abstract science has proceeded from that fountain head. Accepting logic as the science of the formal laws of thought, it is a directly

- M. Littre, in his 'Auguste Comte et la Philosophie Positive,' has pointed this out to Mr. Spencer, who, however, has failed entirely to M. Littre's observations. That is likely enough to happen to a man who, insteed of receiving ideas from hats, is occupied in imposing his ideas upon the facta. 
obvious assertion to make, that the laws of thought are the subject of psychology, and therefore logic, as a science, must be a part of psychology. And yet you make logic, as a part of abstract science, "widely unlike" psychology! But when you have done that, when you have taken logic into the ideal region, you are driven, when you come to deal with the concrete science of psychology, to do what ? Why, positively to inake a division of the concrete science into abstract, general or universal, call it what you will, and into non-universal, particular, or concrete. How the results of this general or universal psychology as a concrete science are to be distinguished from the science of the formal laws of thought, must pass the understanding of any one but a metaphysician who does not feel it necessary to have distinct ideas. The real ground for the untenable distinction is the assumption that the word abstract shall mean something widely different from, essentially beyond, the general, to wit, something which is and yet is not; transcends all human experience, and yet somehow comes into human experience; is a generalisation from observation, and yet is essentially different from a generalisation. Between sciences which deal with relations apart from realities, and sciences which deal with realities, the distinction, says Mr. Spencer, " is the widest possible; since being, in some or all of its attributes, is common to all sciences of the second class, and excluded from all sciences of the first." As if it were possible to one who tries to have definite ideas beneath words, to conceive of thought otherwise than as being l Most writers who have studied the matter now admit, too, that, whatever be the nature of mind, all its manifestations are the dynamical expressions of actual organised results, which are themselves built up from the relations between the individual and external nature. So much for "abstract science" when tried by an experimental test. Abstract concrete sciences treat of the relations among realities, not as usually manifest, but as manifest in their different modes when they are artificially separated; they are "partially ideal," for they are ideal relatively to the concrete- " have for object analytical interpretation," "the laws of combination of matter and motion, not as actually displayed, but as they would be displayed in the absence of interference"; they may be defined as the "laws of the factors." The concrete sciences, on the other hand, deal with the heterogenons combination of forces that constitute actual phenomena; they aim, not to separate and generalise apart the components of all phenomena, "but to explain each phenomenon as a product of these components;" they are real, "synthetical interpretation" is their object, and they may be defined as the "laws of produrts." To any one who has a practical knowledge of the "abstract-concrete science" of chemistry and the "concrete science" of physiology, these observations must, we fear, appear simply 
astounding; but it would carry us much too far to set forth what we conceive to be the manifest errors and inconsistencies of them. Take one example, that of chemistry, as a teat: so far from its aim being merely analytical interpretation, a most important part of organic chemistry is the formation of organic products.* In 1828, Wöhler artificially produced urea, and in 1831 formic acid, the first term of the fatty acids; in 1845, Kolbe produced, artificially, acetic acid, as derivatives of which are obtained acetone, marsh gas, ethylene, methyl, \&c. Since then the production of the compound ammonias has proved that the natural alkaloids, quinine, morphia, strychnia, will one day be obtained; the production of glycerides from glycerine and fatty acids renders it probable that the natural fats will soon be obtained; and the chemists are confident that sugar and albumen will not elude them long. While chemistry is not purely analytical, physiology is very far from being synthetical. The physiology of nervous element is almost entirely in the hands of the chemists, and of those who, like Du Bois Raymond, Matteuci, Pflüger, Helmholtz, and Arnold von Bezold, are investigating the electrical relatious of nerve. The researches of Graham into the "colloidal" condition of matter have almost broken down the barrier between the organic and the inorganic; and are of themselves sufficient to show the untenableness of Mr. Spencer's division of science into abstract-concrete and concrete. We are sorry to say so, but it appears to us that Mr. Spencer has but a superficial acquaintance with the sciences of chemistry and physiology; and that he seems far more disposed to go astray in the tempting path of speculation than to apply himself to the tedious and uninviting work of learning what has been done in science.

We make the observation with less diffidence because, in Mr. Spencer's exposition of his reasons for dissenting from M. Comte, there is exhibited a misinterpretation or misunderstanding of Comte's philosophy, which is surprising and almost incredible in a critic. If he has drawn his knowledge of a great part of Comte from that most miserable outline of the positive philosophy which Mr. Lewes produced, as a note in the appendix would seem to indicate, the errors may be intelligible, but none the less they are inexcusable. One might have thought that the first thing to do, before

* It appear from a note, that Profeceor Frankland pointed this out to Mr. Spencer; bat, will any one be murprised to learn, without effeet? How could Mr. Spencer give up such a big theory, because a fact or two wore against it ? An exception, do you eay! Nonsense : only an epparent exception which in reality confirms the theory. We must acquiesce; for it is vain to argue with any one who will arbitrarily give to words whatever meaning he thinks fit. Note only the interesting fact that an anthor writing upon the clessification of the sciences needed to have such an elementary truth pointed out to him! If that was necessary, it is no wonder that he did not appreciate the fact when it. was pointed oat to him. 
criticising an author, was to read him. Not having Comte's works at hand, we cannot take each of the passages which he has quoted with the purpose of contrasting them with his own opinions, and point out, as might easily be done, in one case after another, how he has failed to appreciate the spirit of M. Comte's writings, how he has misinterpreted some passages, and how unfairly he has represented others. All this, too, with no other aim seemingly but to minister to his own glorification by showing how he differs from the great French philosopher! One most flagrant specimen, however, we give.

The following passage is quoted by Mr. Spencer as expressing one of the cardinal doctrines of M. Comte :-

“Ce n'est pas aux lecteurs de cet ouvrage que je croirai jamais devoir prouver que les idées gouvernent et bouleversent le monde, ou, en d'autres termes, que tout le mécanisme social repose finalement sur des opinions. Ils savent surtout que la grande crise politique et morale des sociétés actuelles tiennent, en dernière analyse, d l'anarchie intellectuelle."

By the side of this passage Mr. Spencer puts a statement of his own opinions, which is to the effect that ideas do not govern and overthrow the world, but that the world is governed or overthrown by feelings. That is his tale; and now, with a full sense of responsibility, a deliberate remark shall be made, and it is this : that if there is one doctrine more distinctly and more persistently taught than another throughout the 'Positive Philosophy,' it is that feeling or the affective life, and not intellect, is the real motive force of human action. It is a wrong, a wicked wrong, on Mr. Spencer's part to put forward the mutilated passage which he has quoted, as embodying the doctrine of $\mathbf{M}$. Comte, whose actual opinions on that matter are very much what he represents his own to be. Certainly it argues a strange piece of fortune or a very convenient method of observation to have contrived to get hold of such a fragment, when, without trouble, fifty passages might have been got which directly contradicted it. Here is one which happens to be available:"Mind must tend more and more to the supreme direction of affairs; but it can never attain it, owing to the imperfection of our organism, in which the intellectual life is the feeblest part; and thus it appears that the real office of mind is deliberative; that is, to modify the material preponderance, and not to impart its habitual impulsion."* This passage is a faint reflection of what is taught throughout the 'Positive Philosophy' with greater emphasis and greater distinctness; and it is inconceivable how any one acquainted with M. Comte's writings should ever have thought otherwise. But Mr. Spencer appears not to see M. Comte's philosophy, nor scientific results, nor

\footnotetext{
- 'Positive Philosophy,' vol. ii, p. 240, H. Martineau's translation.
} 
anything else, except as they are distorted through the medium of his preconceived ideas.

The essay on the 'Classification of the Sciences' is the most unsatisfactory production Mr. Spencer has yet given to the world; at the best it is an ambitious failure which serves only to exhibit its author in a less favorable light than he has hitherto appeared in, and to suggest grave distrust of his soundness as a thinker. To the extremest jot and tittle it justifies the observations made at the beginning of this notice. One cannot but designate as unphilosophical an essay which exhibits confusion and error of thought on matters which a single chapter of Mr. J. S. Mill might have cleared up; it is certainly unscientific, for its foundations are laid where science has no concern; and it must strike many people as startling, if not as something more than startling, for it presents the singular spectacle of a writer deeming it to add to his credit to be ignorant of the state of knowledge on the subject of which he writes. The classification is not a classification arrived at from a consideration of the facts of science; it is a classification made by the violent superinduction of obsolete metaphysical ideas on facts, and, in our opinion, has no better chance of enduring than darkness has when the sun rises. Long after it has sunk into a nameless oblivion the classification which it presumes to criticise and is intended to supersede will be a subject of discussion. Taking it on its own ground, there is a notable deficiency observable in it: to complete its retrogressive character and to fill up the measure of its iniquity, there is needed the addition of one more division-that of "Ontology." H. M.

Some Remarks on the Ulster Revival, so named, of 1859. By Henry Mac Cormac, M.D. Edin.

"For God has not given us the spirit of fear, but of power and love and a round mind."-2 Trx. $i, 7$.

Av eye-witness of this remarkable phenomenon, the Ulster Revival of 1859 , I should wish to dilate, yet a little, upon it, ere the period for doing so passes entirely away. The agitation which it engendered still lingers somewhat. And as like causes produce like effects, more revivals may perhaps be anticipated, when the seeds so profusely scattered shall experience with time the requisite development.

The revival movement, with all its striking anomalous accompaniments, was confined to members of the Reformed, and more es- 


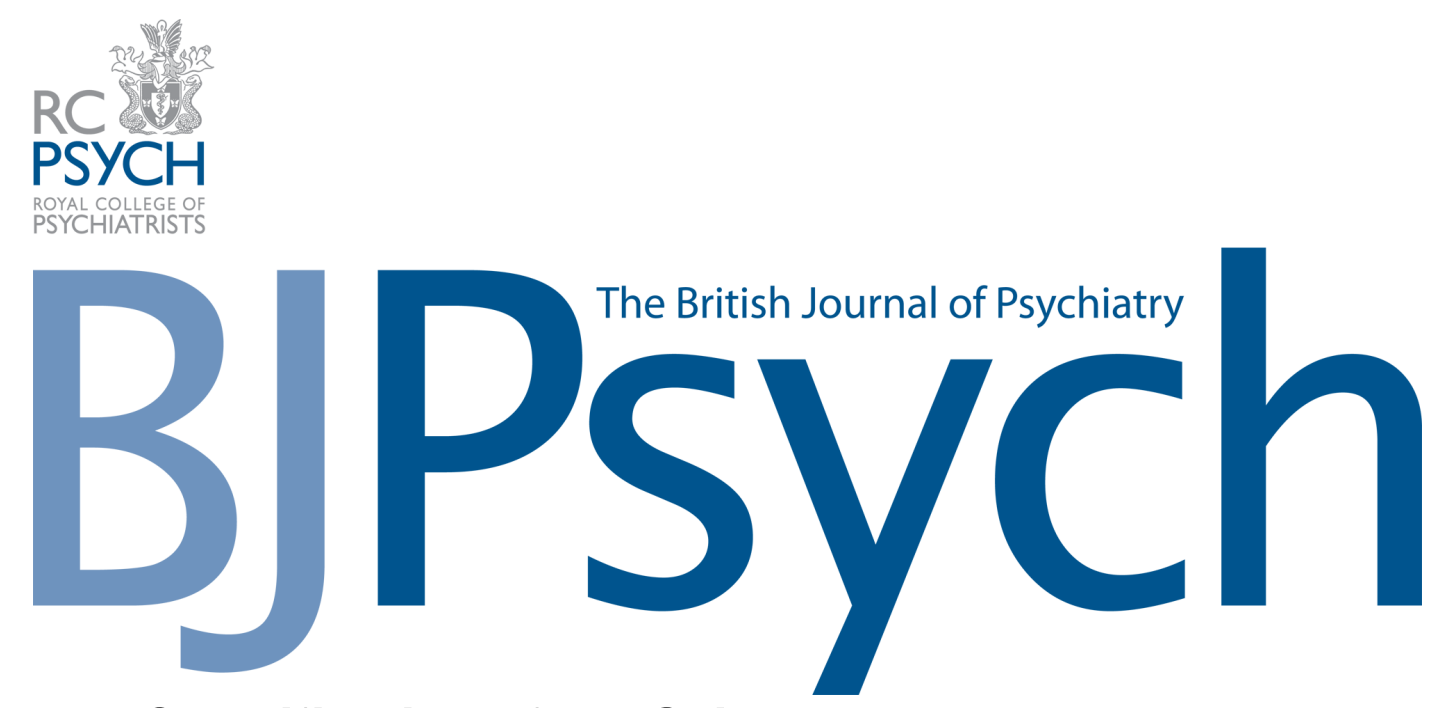

\section{The Classification of the Sciences}

H.M.

BJP 1864, 10:145-157.

Access the most recent version at DOI: 10.1192/bjp.10.50.145

\begin{tabular}{cl}
\hline References & $\begin{array}{l}\text { This article cites } 0 \text { articles, } 0 \text { of which you can access for free at: } \\
\text { http://bjp.rcpsych.org/content/10/50/145.citation\#BIBL }\end{array}$ \\
$\begin{array}{c}\text { Reprints/ } \\
\text { permissions }\end{array}$ & $\begin{array}{l}\text { To obtain reprints or permission to reproduce material from this paper, please write } \\
\text { to permissions@rcpsych.ac.uk }\end{array}$ \\
$\begin{array}{r}\text { You can respond } \\
\text { to this article at } \\
\text { Downloaded } \\
\text { from }\end{array}$ & $\begin{array}{c}\text { hletters/submit//bjprcpsych;10/50/145. } \\
\text { Published by The Royal College of Psychiatrists }\end{array}$ \\
\hline
\end{tabular}

To subscribe to The British Journal of Psychiatry go to: http://bjp.rcpsych.org/site/subscriptions/ 